\title{
The Interest Rate Parity in Fragile Five Countries: Evidence from Unit Root Tests with Breaks
}

\author{
Kırılgan Beşli Ülkelerinde Faiz Oranı Paritesi: Kırılmalı Birim Kök \\ Testlerinden Kanıtlar
}

\section{Mehmet ALTUNTAŞ ${ }^{1}$}

\section{ABSTRACT}

This study analyzes the validity of the uncovered interest rate parity for Brazil, India, Indonesia, South Africa, and Turkey, which are grouped as The Fragile Five countries within the literature. The econometric analysis section of the study benefits from unit root tests, a common method that researchers have started to utilize recently. For this reason, we used Dickey and Fuller (1979), Augmented Dickey and Fuller (1981), Philips and Perron (1988), Kwiatkowski et al. (1992), Perron (1989) unit root test with one break, Zivot and Andrews (1992) unit root test with one break, and Enders and Lee (2012) Fourier-ADF unit root tests. In line with the results of the analysis, we obtained strong evidence regarding the validity of the uncovered interest rate parity for Brazil, Indonesia, and Turkey. Results for India vary according to the structure of the break and where the structural break is taken into consideration. This shows that structural breaks and the economic circumstances of the period that the data set is from should be considered. Although results for South Africa show that interest rate parity is generally valid, results for the Fourier-ADF test, which allows for smooth breaks, offered evidence that the interest rate parity was not valid in these countries.

Keywords: Interest rate parity, The Fragile Five Countries, Unit root tests, Financial integration, Emerging market countries

Jel Code: B26, C22, F31

öz

Bu çalışmada literatürde Kırılgan Beşli ülkeleri olarak gruplandırılan Brezilya, Hindistan, Endonezya, Güney Afrika ve Türkiye için kapsanmamış faiz oranı paritesinin geçerliliği araştırılmıştı. Çalışmanın ekonometrik
${ }^{1}$ Asst. Prof. Department of Logistics, Nisantasi University, Istanbul, Turkey

ORCID: M. A. 0000-0003-2040-3168

Corresponding author/Sorumlu yazar: Mehmet ALTUNTAŞ,

Asst. Prof. Department of Logistics, Nisantasi University, Istanbul, Turkey

E-mail/E-posta:

mehmet.altuntas@nisantasi.edu.tr

\section{Submitted/Başvuru: 15.05.2021 \\ Revision Requested/Revizyon Talebi: 05.06.2021 \\ Last Revision Received/Son Revizyon: \\ 12.06.2021 \\ Accepted/Kabul: 13.06.2021}

Citation/Atıf: Altuntas, M. (2021). The interest rate parity in fragile five countries: evidence from unit root tests with breaks. Iktisat Politikas Araştırmaları Dergisi - Journal of Economic Policy Researches, 8(2), 327-349.

https://doi.org/10.26650/JEPR.937488 
analiz bölümünde son dönemlerde araştırmacılar tarafından yaygın olarak kullanılan birim kök testlerinden yararlanılmıştır. Bu noktada Dickey ve Fuller (1979), Genişletilmiş Dickey ve Fuller (1981), Philips ve Perron (1988), Kwiatkowski, Phillips, Schmidt ve Shin (1992), Perron (1989) tek kırılmalı birim kök, Zivot ve Andrews (1992) tek kırılmalı birim kök ve Enders ve Lee (2012) Fourier-ADF birim kök testleri kullanılmıştır. Analiz sonuçları doğrultusunda Brezilya, Endonezya ve Türkiye için kapsanmamış faiz oranı paritesinin geçerliliğine dair güçlü kanıtlar elde edilmiştir. Hindistan ilişkin sonuçlar yapısal kırılmanın dikkate alındığı durum ve dikkate alınan yapısal kırılmanın yapısına göre değişiklik göstermektedir. Bu durumda yapısal kırılmaların dikkate alınması ve veri setine ilişkin dönemin konjonktürel yapısının iyi bilinmesi konusunu gündeme getirmektedir. Güney Afrika'da ise sonuçlar çoğunlukla faiz oranı paritesinin geçerli olduğu yönünde olmasına rağmen, yumuşak kırılmalara izin veren Fourier-ADF testine ilişkin sonuçlar bu ülkelerde faiz oranı paritesinin geçersiz olduğuna dair kanıtlar sunmuştur.

Anahtar Kelimeler: Faiz oranı paritesi, Kırılgan Beşli Ülkeleri, Birim kök testleri, Finansal entegrasyon, Gelişmekte olan piyasa ülkeleri

Jel Kodları: B26, C22, F31

\section{Introduction}

Based on the difference between the exchange rates and the countries' interest rates, in essence, the IRP is frequently used in behavior analyses in foreign exchange markets (Stein, 1962; Glahe, 1967). Melvin and Norrbin (2013) defined IRP as a basic approach that explains the relationship between the earnings of financial assets traded in different markets (Melvin \& Norrbin 2013, p. 115). In other words, IRP states that similar financial assets priced in different currencies should have the same earning rate (Krugman \& Obstfeld 2009, p. 336). In short, the IRP can be expressed as the equilibrium between the interest rate applied to domestic financial assets and the earnings expected from foreign financial assets (Claassen, 1996, p. 41).

The literature shows that studies conducted on IRP are essential in two aspects. The first one is the analysis of the efficiency of foreign exchange and international money markets. If we define the concept of an efficient market that contains all the information, extraordinary profits are eliminated, especially for arbitragers. ${ }^{1}$ Secondly, it is used for the determination of the exchange rate based on the asset market approach (Taylor, 1987a, p. 429). IRP has two classifications: The covered interest rate parity (CIRP) and the uncovered interest rate parity (UIRP). The concept of the CIRP emerges for the first time in the studies of Keynes (1923) and Einzig (1937) on exchange rate movements, money markets, and arbitrage transactions (Fong, Valente, \& Fung, 2010, p. 1098). This approach involves the transaction of selling expected future foreign exchange earnings in the current period through a forward contract to avoid unexpected losses by possible sudden shocks in exchange rates. The other approach,

\footnotetext{
1 To put in simpler terms, arbitrage is purchasing at a lower price and selling at a higher one. It is a trading strategy that benefits from profit opportunities that arise from price differences (Feenstra \& Taylor 2012, p. 43).
} 
which involves the UIRP, asserts that the difference between the interest rates of two countries is equal to the expected value change in the exchange rate (Rowland, 2003, p. 3). In other words, it states that a difference between domestic and foreign exchange rates should be equal to the "expected" change in the future value of the exchange rate. No contracts are executed to avoid foreign exchange risk in this approach. Transactions are carried out with the spot exchange rate. This theory is one of the three fundamental theories used as a basis of macroeconomic models for open economies and international finance models. ${ }^{2}$ This approach is also used in addition to other important models for determining the exchange rate, such as the Overshooting Model, monetary exchange rate models, and Krugman's target zone model (McAVinchey \& MacDonald 1990; Bekaert, Wei, \& Xing, 2007).

The purpose of this study is to analyze the validity of the IRP hypothesis for The Fragile Five group of countries consisting of Brazil, India, Indonesia, South Africa, and Turkey. Morgan Stanley came up with The Fragile Five classification in 2013, and this classification is based on the monetary policies of the USA, which affect these countries to a great extent. Moreover, The Fragile Five has similarities in budget imbalance, growth underperformance, high current deficit, inflation, and foreign debts (Hayaloğlu, 2015, p. 133). Departing from other studies that have tested whether the IRP holds, this study will contribute to the relevant literature by combining its sample group with its application of tests for different specifications. On the contribution in terms of the sample group, some studies within the literature have conducted analyses by including only one or a few of the five countries (Brazil, India, Indonesia, South Africa, and Turkey) in the sample group. The validity of the IRP hypothesis was studied by Sachsida, Ellery, \& Teixeira, (2001) for Brazil; Erdemlioğlu (2007) and Karahan and Çolak (2012) for Turkey; Büberkökü (2020) for Turkey, South Africa, and Indonesia; Chang and Su (2015) for Indonesia; Tse and Wald (2013) for Brazil; Skinner and Mason (2011) for Brazil and South Korea; Baharumshah, Liew, \& Haw (2009) for Indonesia and India; Baharumshah, Liew, \& Hamzah (2008) for India; Ferreira and León-Ledesma (2007) for Brazil and Turkey and Francis, Hasan, \& Hunter (2002) for India and Turkey. However, we saw no studies that focused on The Fragile Five countries among the studies that analyze the validity of the IRP hypothesis. For that reason, our study will contribute to the currently limited literature on this group of countries. In addition, all countries in the sample group are emerging market countries ${ }^{3}$. When the studies on developing markets are examined, the absence of a study focusing on fragile five countries will contribute to the studies literature in developing countries.

\footnotetext{
2 The three basic theories involved here are the purchasing power parity, the exchange rate equilibrium, and the UIRP (Lothian \& Wu 2011, p. 449).

${ }^{3}$ https://www.msci.com/market-classification, Accessed January 8, 2020.
} 
Another contribution of our study to the literature will be the large scale of the method implemented. Many studies have been conducted to test the validity of the IRP hypothesis with the unit root method within the literature. The empirical analysis section of this study also uses the unit root method in line with the literature and theories. Within that scope, we first analyzed the validity of the IRP hypothesis with classical unit root tests that do not include structural breaks, such as Dickey and Fuller (DF) (1979), Augmented Dickey and Fuller (ADF) (1981), Philips and Perron (PP) (1988), and Kwiatkowski et al. (KPSS) (1992). Then we used Perron (1989) and Zivot and Andrews (ZA) (1992) unit root tests with one break and different specifications to determine the break year by taking structural breaks that may occur in economic circumstances into consideration. Finally, we used the Enders and Lee (2012) Fourier-ADF unit root test, which can capture all kinds and numbers of breaks, keeping in mind that structural breaks with several and different forms may have occurred in the economy in the relevant sample period. We analyzed with different specifications with the help of relevant tests and revealed in the findings whether structural breaks, the model implemented, and the test methodology affected the results. At this point, we think that our study will contribute to the literature thanks to its extensive coverage of methods, which will allow researchers to determine which tests to select in their analyses and see the effects of the differences in methodology on the results. Moreover, this study differs from previous research because it provides valuable, compact information on the five countries as a group to policymakers working on The Fragile Five.

\section{Theoretical Framework}

In 1973, many countries opted to switch to a free-floating exchange rate regime with the collapse of the Bretton Woods system. Allowing for fluctuations in the exchange rates showed the considerable extent of the exchange rate volatility. Accordingly, economists started to create exchange rate behavior models to determine what affected exchange rate fluctuations (Husted \& Melvin 2013, p. 285). These models have become the primary theoretical tools to analyze the exchange rate fluctuations and have focused on explaining the role of changes in financial market factors (interest rates and expectations on future values of asset prices) on the exchange rate volatility. The basic version of the financial approach for determining exchange rates is the monetary approach. This approach assumes that the domestic and foreign financial assets are perfect substitutes, which means the equilibrium between the earning rates of various assets. This equilibrium between domestic and foreign financial assets is called the IRP (Claassen, 1996, p. 41).

The IRP is used to explain the relationship between the earnings of financial asset investments between two countries. It arises from profit-oriented arbitrage activities, especially from the scope of interest rate arbitrage (Michel \& Norrbin 2013, p. 115). IRP 
differs from other approaches because it takes macroeconomic structures and capital mobilities into consideration. The IRP approach argues that the interest differences between countries should be equalized by using the forward and spot exchange rate differences to remain in equilibrium. The IRP has two categories, namely, the CIRP and the UIRP.

The UIRP approach does not consider the risk factor. Investments are made without a forward contract to avoid foreign exchange risk. In other words, this is a situation where the arbitrager takes the currency risk that may arise in exchange rate volatility in the future period into consideration. Equation 1 shows the formulation for the UIRP.

$$
E_{t}=\frac{\left(1+i_{t}\right)}{\left(1+i_{t}^{*}\right)} * E_{t+1}^{e}
$$

where $E_{t}$ represents the nominal exchange rate, $i_{t}$ represents the domestic interest rate, $i_{t}^{*}$ represents the foreign interest rate, and $E_{t+1}^{e}$ represents the nominal exchange rate expected for the upcoming period. Equation 1 shows that the UIRP can be expressed as the equilibrium between the interest rate applied to domestic financial assets and the earnings expected of foreign financial assets. After dividing both sides of Equation 1 by the expected exchange rate variable and then taking the natural logarithm, this equation can also be presented in a similar way to Equation 1.1.

$$
E_{t}-E_{t+1}^{e}=i_{t}-i_{t}^{*}
$$

The IRP theory states that the difference between the interest rates of two countries should be equal to the expected change in the exchange rate (Krugman \& Obstfeld 2003).

The risk factor is taken into consideration with the CIRP. In this context, the risks arising from the exchange rate in the upcoming period can be eliminated by executing a forward contract. Equation 2 shows the formulation for the CIRP.

$$
E_{t}=\frac{\left(1+i_{t}\right)}{\left(1+i_{t}^{*}\right)} * F_{t}
$$

where $F_{t}$ represents the forward exchange rate. The discount or premium applied to the forward exchange rate equal to the interest rate difference between two countries that the investor plans to invest in (and the forward exchange rate fulfilling this equilibrium) is called the CIRP. When both sides of Equation 2 are modified by subtracting one, it takes the form shown in Equation 2.1.

$$
\frac{F_{t}-E_{t}}{E_{t}}=\frac{\left(1+i_{t}\right)}{\left(1+i_{t}^{*}\right)}-1=>\frac{i-i_{t}}{1+i_{t}^{*}}
$$

There are two different situations according to Equation 2.1. If $\frac{F_{t}-E_{t}}{E_{t}}>\frac{i-i_{t}}{1+i_{t}^{*}}$, the future exchange rate difference will be greater than the interest rate difference, and it will be more profitable to invest in foreign funds. In the second situation, where $\frac{F_{t}-E_{t}}{E_{t}}<\frac{i-i_{t}}{1+i_{t}^{*}}$, the future 
exchange rate difference is less than the interest rate difference, and it will be more profitable to invest in domestic funds.

\section{Empirical Literature}

A general review of the literature on the IRP hypothesis shows that especially former studies have focused on developed countries. The reason for that is the difficulty of obtaining data on underdeveloped or developing countries for the relevant period (Pasricha, 2006). However, with the recent liberalization of developing economies, the increase in the international trade volume has led researchers to study developing countries. Thus, it is important to research the structure and efficiency of the foreign exchange market, which is the building block of the international economy and finance, and research on the expectations for the upcoming period.

Table 1: Summary for the selected literature

\begin{tabular}{|c|c|c|c|c|}
\hline Study & Country & Period & Method & Results \\
\hline \multicolumn{5}{|c|}{ Panel A: Time Series Studies } \\
\hline Mishkin (1984) & 7 OECD countries & 1967Q2-1979Q2 & $\begin{array}{c}\text { Regression Analysis } \\
\text { (GLS) }\end{array}$ & UIRP is not valid. \\
\hline Sharpe (1984) & Australia & $\begin{array}{c}\text { 1978-1982 } \\
\text { (Weekly data) }\end{array}$ & ARIMA Models & CIRP is valid. \\
\hline Taylor (1987b) & $\begin{array}{c}\text { USA (USD), } \\
\text { Germany (Deutsche } \\
\text { Mark), Japan } \\
\text { (Japanese Yen), } \\
\text { France (French } \\
\text { Franc), Italy } \\
\text { (Italian Lira), and } \\
\text { Netherlands (Dutch } \\
\text { Guilder) }\end{array}$ & $\begin{array}{l}\text { 1979:M07- } \\
\text { 1986:M01 }\end{array}$ & Wald, LR, and LM & $\begin{array}{l}\text { UIRP is not valid } \\
\text { except Italian } \\
\text { Lira/Sterling, and } \\
\text { Deutsche Mark/USD. }\end{array}$ \\
\hline Ito (1988) & $\begin{array}{c}\text { Japan (Japanese Yen) } \\
\text { and USA (USD) }\end{array}$ & $\begin{array}{c}\text { 1973:M01- } \\
\text { 1977:M03, } \\
\text { 1977:M04- } \\
\text { 1980:M12, and } \\
\text { 1981:M01- } \\
\text { 1985:M03 }\end{array}$ & VAR Analysis & $\begin{array}{c}1973-1977 \rightarrow \text { UIRP } \\
\text { and CIRP are not } \\
\text { valid. } \\
\text { 1977-1980 and 1980- } \\
1985 \rightarrow \text { UIRP and } \\
\text { CIRP are valid. }\end{array}$ \\
\hline Taylor (1989) & $\begin{array}{l}\text { USA (USD), Japan } \\
\text { (Japanese Yen), } \\
\text { France (French } \\
\text { Franc), Italy } \\
\text { (Italian Lira), and } \\
\text { Netherlands (Dutch } \\
\text { Guilder) }\end{array}$ & $\begin{array}{l}\text { 1979:M07- } \\
\text { 1986:M01 }\end{array}$ & $\begin{array}{c}\text { VAR Analysis and } \\
\text { ARCH }\end{array}$ & $\begin{array}{c}\text { VAR } \rightarrow \text { UIRP is valid } \\
\text { for all currencies. } \\
\text { ARCH } \rightarrow \text { UIRP is } \\
\text { valid for Deutsche } \\
\text { Mark/USD, Dutch } \\
\text { Guilder/USD, and } \\
\text { Dutch Guilder/ } \\
\text { Deutsche Mark. }\end{array}$ \\
\hline
\end{tabular}




\begin{tabular}{|c|c|c|c|c|}
\hline $\begin{array}{l}\text { Kugler and Neusser } \\
\text { (1993) }\end{array}$ & OECD Countries & $\begin{array}{l}\text { 1980:M01- } \\
\text { 1970:M12 }\end{array}$ & $\begin{array}{l}\text { VAR Analysis, } \\
\text { Gourieroux \& } \\
\text { Peaucelle (1989) } \\
\text { Cointegration }\end{array}$ & $\begin{array}{l}\text { IRP is valid in the } \\
\text { long term and invalid } \\
\text { in the short term. }\end{array}$ \\
\hline $\begin{array}{l}\text { Goodwin and Grennes } \\
\text { (1994) }\end{array}$ & $\begin{array}{l}\text { USA, Canada, } \\
\text { England, } \\
\text { Belgium, Italy, } \\
\text { France, Germany, } \\
\text { Netherlands, } \\
\text { Switzerland, and } \\
\text { Japan }\end{array}$ & $\begin{array}{l}\text { 1975:M01- } \\
\text { 1987:M02 }\end{array}$ & $\begin{array}{l}\text { Engle \& Granger } \\
\text { Cointegration and } \\
\text { Johansen \& Juselius } \\
\text { Cointegration }\end{array}$ & IRP is valid. \\
\hline Jorion (1996) & $\begin{array}{c}\text { USA, England, and } \\
\text { Germany }\end{array}$ & $\begin{array}{l}\text { 1973:M08- } \\
\text { 1991:M12 }\end{array}$ & $\begin{array}{c}\text { Regression Analysis } \\
\text { (OLS) }\end{array}$ & IRP is valid. \\
\hline Moosa (1996) & $\begin{array}{c}\text { Australia and New } \\
\text { Zealand }\end{array}$ & $\begin{array}{l}\text { 1985:M01- } \\
\text { 1994:M12 }\end{array}$ & $\begin{array}{l}\text { Phillips \& Ouliaris } \\
\text { (1990) Cointegration }\end{array}$ & CIRP is not valid. \\
\hline $\begin{array}{l}\text { Balke and Wohar } \\
\text { (1998) }\end{array}$ & England and USA & $\begin{array}{l}\text { 1974:M01- } \\
\text { 1993:M09 }\end{array}$ & $\begin{array}{c}\text { Regression Analysis } \\
\text { (OLS and ARCH } \\
\text { Model) }\end{array}$ & CIRP is not valid. \\
\hline Sachsida et al. (2001) & Brazil & $\begin{array}{l}\text { 1984:M01- } \\
\text { 1998:M10 }\end{array}$ & $\begin{array}{l}\text { Regression Analysis } \\
\text { (OLS) }\end{array}$ & $\begin{array}{l}\text { UIRP is valid for the } \\
\text { period of flexible } \\
\text { exchange rate } \\
\text { regimes. }\end{array}$ \\
\hline Francis et al. (2002) & $\begin{array}{l}9 \text { Developing Market } \\
\text { Economies }\end{array}$ & $\begin{array}{c}\text { 1980-2000 } \\
\text { (Monthly Data) }\end{array}$ & $\begin{array}{l}\text { Regression Analysis } \\
\text { (GARCH Model) }\end{array}$ & UIRP is not valid. \\
\hline $\begin{array}{l}\text { Holmes and Maghrebi } \\
\text { (2004) }\end{array}$ & $\begin{array}{l}\text { Korea, Malaysia, } \\
\text { Singapore, Thailand, } \\
\text { Japan, and the USA }\end{array}$ & $\begin{array}{l}\text { 1977:M01- } \\
\text { 2000:M03 }\end{array}$ & ADF and STAR & IRP is valid. \\
\hline $\begin{array}{l}\text { Goh, Lim, \& Olekalns } \\
\text { (2006) }\end{array}$ & Malaysia & $\begin{array}{l}\text { 1978:M01- } \\
\text { 2002:M02 }\end{array}$ & SWARCH & $\begin{array}{l}\text { UIRP is valid when } \\
\text { regime changes } \\
\text { are taken into } \\
\text { consideration. }\end{array}$ \\
\hline $\begin{array}{l}\text { Adrangi, Raffiee, \& } \\
\text { Shank (2007) }\end{array}$ & $\begin{array}{l}\text { Korea, Philippines, } \\
\text { and Thailand }\end{array}$ & $\begin{array}{l}\text { 1978:M05- } \\
\text { 1997:M01 }\end{array}$ & $\begin{array}{c}\text { VAR Analysis and } \\
\text { Regression Analysis } \\
\text { (ARCH and GARCH } \\
\text { Models) }\end{array}$ & UIRP is not valid. \\
\hline Erdemlioğlu (2007) & Turkey & $\begin{array}{l}\text { 2001:M12- } \\
\text { 2007:M06 }\end{array}$ & $\begin{array}{c}\text { Regression Analysis } \\
\text { (ARCH and GARCH } \\
\text { Models) }\end{array}$ & UIRP is not valid. \\
\hline $\begin{array}{l}\text { Ferreira and León } \\
\text {-Ledesma (2007) }\end{array}$ & $\begin{array}{c}\text { Argentina, Brazil, } \\
\text { Mexico, Turkey, } \\
\text { Chile, France, } \\
\text { Germany, Italy, } \\
\text { Spain, USA, and } \\
\text { England }\end{array}$ & $\begin{array}{l}\text { 1970:M03- } \\
\text { 2003:M08 }\end{array}$ & $\begin{array}{l}\text { ADF, KPSS, ERS, } \\
\text { Elliott (1999) (DF- } \\
\text { GLS), Perron (1997), } \\
\text { and MTAR Unit Root }\end{array}$ & IRP is valid. \\
\hline $\begin{array}{l}\text { Baharumshah et al. } \\
\text { (2008) }\end{array}$ & ASEAN-5 & $\begin{array}{l}\text { 1977:M01- } \\
\text { 2002:M01 }\end{array}$ & KSS & $\begin{array}{l}\text { IRP is valid for } \\
\text { Singapore, Indonesia, } \\
\text { Thailand, and the } \\
\text { Philippines. }\end{array}$ \\
\hline
\end{tabular}




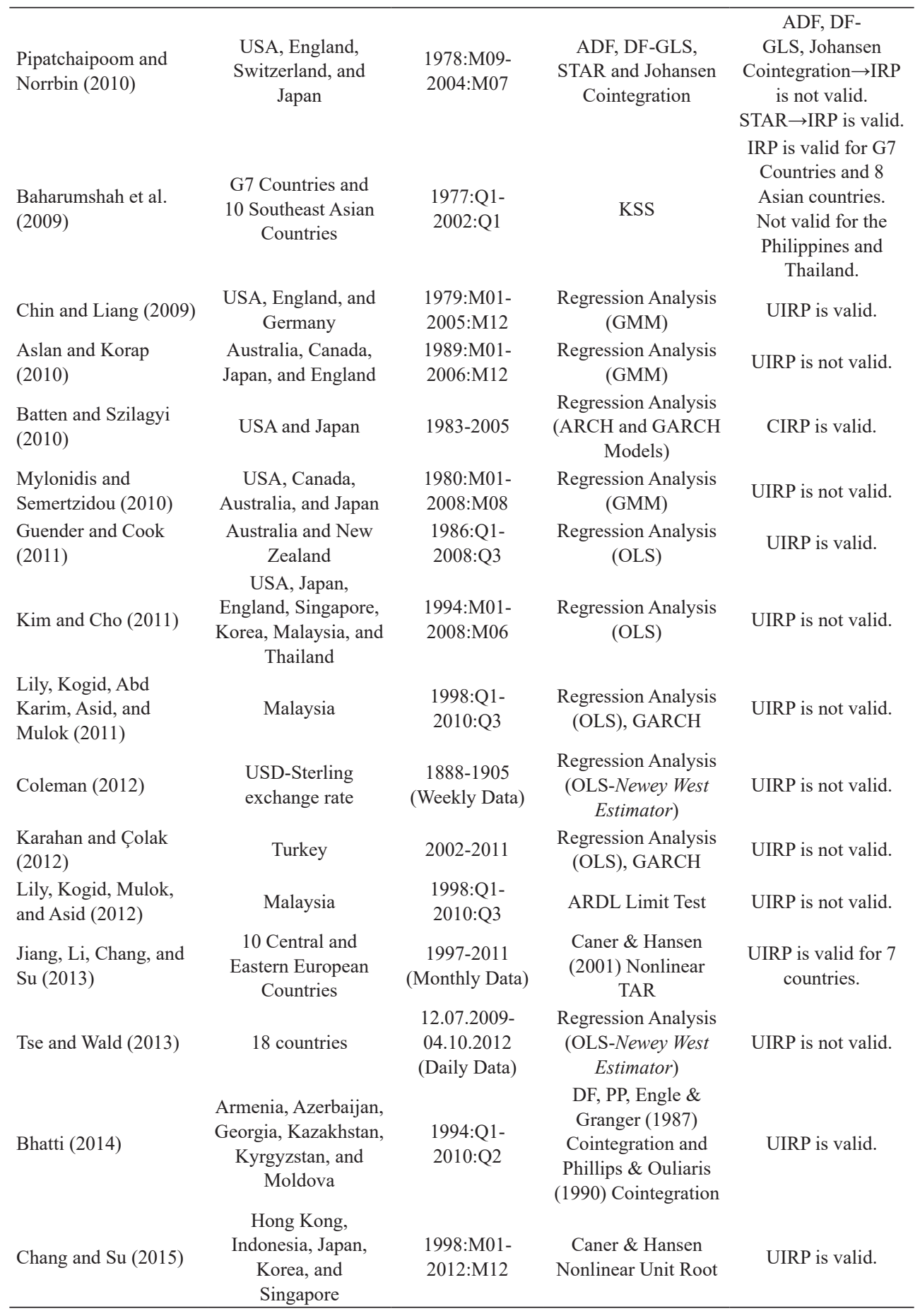




\begin{tabular}{lcccc}
\hline Fukuda (2016) & USA and Japan & $\begin{array}{c}2007-2009 \\
\text { (Daily Data) } \\
\text { Suh and Kim (2016) }\end{array}$ & GARCH Test & CIRP is not valid. \\
& Korea & $\begin{array}{c}15.08 .2014 \\
\text { (Daily Data) }\end{array}$ & $\begin{array}{c}\text { Regression Analysis } \\
\text { (OLS) }\end{array}$ & CIRP is valid. \\
Büberkökü (2020) & Turkey, South Africa, & 2003:M01- & ADF and Regression & EKK $\rightarrow$ UIRP is not \\
& Mexico, Colombia, & Analysis (OLS) & ADF $\rightarrow$ UIRP is valid. \\
\hline
\end{tabular}

Note: GLS: Generalized Least Squares, LR: Likelihood Ratio Test, LM: Lagrange Multiplier Test, VAR: Vector Autoregression, OLS: Ordinary Least Squares, GARCH: Multivariate Generalized Autoregressive Conditional Heteroscedasticity Framework, STAR: Smooth Transition Autoregressive Methodology, ARCH: Autoregressive Conditional Heteroskedasticity, SWARCH: Switching ARCH, ERS: Elliott, Rothenberg, and Stock Unit Root Tests, TAR: Threshold Autoregressive Model, MTAR: Momentum TAR, KSS: Kapetanios, Shin, and Snell, GMM: Generalized Method of Moments.

Table 1 lists the studies that use the IRP approach, one of the theoretical approaches used to determine the exchange rate. A general review of the data collected within the literature shows the research focus to be on developed countries and Middle Eastern countries. This may be due to the openness of these countries or to their comprehensive databases. Another issue to point out from the previous literature is that the effects of econometric methods used in the analysis of IRP hypothesis can be seen in the analysis results. The studies conducted by Taylor (1987b) and Taylor (1989) are examples of this. Although Taylor analyzed the validity of the IRP hypothesis for the same country group and the same sample group in the study in 1987, Taylor obtained different results that stemmed from the different econometric methods used and the structure taken into consideration. This revealed the effect that econometric methods had on the results.

Among the studies in Table 1, evidence for the validity of the IRP was given by Sharpe (1984) for Australia; Committeri, Rossi, and Santorelli (1993) for Italy, Germany, and the USA; Berument and Günay (2003) for Turkey; Chin and Liang (2009) for the USA, the UK, and Germany; Batten and Szilagyi (2010) for the USA and Japan; Guender and Cook (2011) for Australia and New Zealand; Kim and Cho (2011) for the USA, Japan, the UK, Singapore, Korea, Malaysia, and Thailand; Lothian (2016) for 17 various countries. Meanwhile, the IRP hypothesis was proven to be invalid by the studies of Moosa (1996) for Australia and New Zealand; Francis et al. (2002) for nine developing market economies; Adrangi et al. (2007) for Korea, the Philippines, and Thailand; Mylonidis and Semertzidou (2010) for the USA, Canada, Australia, and Japan; Lily et al. (2011) for Malaysia; Tse and Wald (2013) for 18 various countries and Fukuda (2016) for the USA and Japan. An analysis of the studies within the scope of the literature review shows that these studies grouped factors such as development level, region, country, or index of openness and as a result, there is no consensus on the validity of the IRP hypothesis due to the different methods and approaches that were used. 
In the analysis of econometric methods used in testing the IRP hypothesis, it is observed that regression analysis, the unit root method, and the cointegration method are the most commonly used methods. This study will also analyze the validity of the IRP hypothesis in The Fragile Five countries by using unit root tests. Moreover, structural breaks will be taken into consideration in the economic models. Despite the concentration of studies that use the unit root method within the literature, there are a limited number of studies that consider structural breaks in economic models. In that regard, our study will contribute to the literature.

\section{Econometric Methodology}

The studies conducted with a scope of empirical analysis of the IRP within the literature show that unit root tests have been commonly used in the econometric analysis sections of such studies. In this study, the validity of the IRP hypothesis for Brazil, India, Indonesia, South Africa, and Turkey, grouped as The Fragile Five countries, will be analyzed with unit root tests. In that regard, classical tests that do not consider structural breaks such as Dickey and Fuller (1979), Augmented Dickey and Fuller (1981), Philips and Perron (1988), and Kwiatkowski et al. (1992) will be utilized first. Perron (1989) unit root test with one break, Zivot and Andrews (1992) unit root test with one break, and the Enders and Lee (2012) Fourier-ADF test, all of which consider structural breaks, will be used later to see whether including structural breaks in the econometric model has any effect on the results.

\subsection{Classical Unit Root Tests}

The time series unit root is based on the unit root test suggested by Dickey and Fuller in 1979. According to this test, the basic model, including the constant term and trend variables, is shown in Equation 3 (Dickey \& Fuller 1979, p. 427).

$$
Y_{t}=a_{o}+b t+\rho Y_{t-1}+\varepsilon_{t}
$$

where $Y_{t}$ shows the dependent variable, $Y_{t-1}$ shows the lags of the dependent variable in the previous period, $a_{o}$ shows the constant term, and $t$ shows the trend variable. $\varepsilon_{t}$ refers to the residuals and is $\varepsilon_{t} \sim i$. i.d. $\left(0, \sigma^{2}\right)$. The DF test tests the presence of a unit root in the absence hypothesis $\left(H_{o}: \rho=1\right)$, against stationarity in the alternative hypothesis $\left(H_{A}: \rho<1\right)$. The test statistic for the DF test is $\hat{\tau}=\frac{\widehat{\rho}-1}{\operatorname{sh}(\widehat{\rho})}$. The DF test does not take the status of autocorrelation and/or unstable variance into consideration in the series. This is because the test methodology is based on the assumption that there is no autocorrelation or unstable variance. Dickey and Fuller (1981) obtained the ADF equation by extending the model related to the DF test for the lags of dependent variance to prevent deviations that may occur at this stage. The main purpose of adding the lags of dependent variance as an 
independent variance into the model is to correct autocorrelation and/or unstable variance. Accordingly, the model related to the ADF test that includes constant and deterministic trend elements is as shown in Equation 4 (Dickey \& Fuller 1981, p. 1065).

$$
\Delta Y_{t}=a_{o}+b t+\alpha Y_{t-1}+\sum_{j=1}^{q} \beta_{j} \Delta Y_{t-j}+\varepsilon_{t}
$$

where $\beta$ is the lag coefficient, $q$ is the parameter showing the lag size and $\alpha=1-\rho$. While determining the lag size in the ADF test, it should be ensured that the size is sufficient to eliminate autocorrelation and/or unstable variance. For this point, the Akaike information criterion (AIC) or the Schwarz information criterion (SC) can be used. The ADF test tests the presence of a unit root in the absence hypothesis $\left(H_{0}: \alpha=0\right)$ against stationarity in the alternative hypothesis $\left(H_{A}: \alpha<0\right)$. The test statistic for the ADF test is $\hat{\tau}=\frac{\widehat{\alpha}}{\operatorname{sh}(\widehat{\alpha})}{ }^{4}$.

Diverging from the ADF test, Philips and Perron (1988) suggested that any autocorrelation and unstable variance could be corrected with a non-parametric approach. Accordingly, unlike the ADF test, the PP test corrects the autocorrelation in the error term by using a nonparametric approach. On that note, the consistent long-term variance estimator is used in the calculation of the test statistic. The test statistic for the PP test is as follows:

$$
\begin{aligned}
& Z_{\widehat{\alpha}}=T \hat{\alpha}-\left(\widehat{\omega}^{2}-\hat{\sigma}_{\varepsilon}^{2}\right)\left(2 T^{-2} \sum_{t=1}^{T} \hat{\varepsilon}_{t}^{2}\right)^{-1} \\
& Z_{\hat{t}}=t_{\widehat{\alpha}}\left(\frac{\widehat{\sigma}_{\varepsilon}^{2}}{\widehat{\omega}^{2}}\right)^{1 / 2}-\frac{1}{2}\left(\widehat{\omega}^{2}-\hat{\sigma}_{\varepsilon}^{2}\right)\left(\widehat{\omega}^{2} T^{-2} \sum_{t=1}^{T} \hat{\sigma}_{\varepsilon}^{2}\right)^{-1 / 2}
\end{aligned}
$$

In Equations 5 and $6, \hat{\sigma}_{\varepsilon}^{2}$ represents the residual variance, $T$ represents the number of observations, and $\widehat{\omega}^{2}$ represents the consistent long-term variance estimator. The autoregressive spectral density estimator and the kernel estimator can be used in the calculation of this estimator ${ }^{5}$.

Another unit root approach used in testing the unit root is the stationarity test suggested by Kwiatkowski et al. (1992). The point that differentiates the KPSS test from the other tests without breaks is that it tests stationarity in the $H_{o}$ hypothesis $\left(H_{o}: \sigma_{u}^{2}=0\right)$ against the presence of the alternative hypothesis unit root $\left(H_{A}: \sigma_{u}^{2}>0\right)$. The model for the KPSS test is as shown in Equation 7 (Kwiatkowski et al., 1992, p. 162).

$$
Y_{t}=a_{o}+b t+r_{t}+\varepsilon_{t}
$$

\footnotetext{
${ }^{4} \tau$ The $\tau$ statistic does not comply with the asymptotic distribution of. Therefore, the critical values in the Dickey and Fuller (1979) study should be used in the decision stage of the DF and the ADF tests.

${ }^{5}$ The hypotheses for the PP test are the same as the ADF test. Moreover, asymptotic distributions of the test statistics used in the PP test are the same as the DF and the ADF tests. Therefore, the obtained test statistic should be compared with the tables listed in Dickey and Fuller (1992) study.
} 
where $r_{t}$ refers to the random walk process and is calculated as $r_{t=} r_{t-1}+u_{t}\left(u_{t} \sim\left(0, \sigma_{u}^{2}\right)\right)$. $\varepsilon_{t}$ refers to stationary errors. The test statistic for the KPSS test is $K P S S=\frac{1}{T^{2}} \frac{\sum_{t=1}^{T} \hat{S}_{t}^{2}}{\widehat{\sigma}_{\varepsilon}^{2}}$. Here, the calculation is as follows $\hat{S}_{t}=\sum_{j=1}^{t} \tilde{\varepsilon}_{j}$. The Kernel estimator can be used in the calculation of $\hat{\sigma}_{\varepsilon}^{26}$.

\subsection{Unit Root Tests With Structural Breaks}

Perron (1989) stated that a stationary process might be expressed as a unit root process (error type 2) in the event of a structural break, if any, in a time series if not considered, which weakens the validity of the test. Perron (1989) noticed that the Great Depression (1929) and the OPEC crisis (1973) led to major changes in the averages of the series and concluded that the non-stationarity processes were actually stationary by including these breaks into the model with the help of dummy variables (Perron 1989, p. 1361). To solve this problem, he suggested a test procedure in which breaks are exogenously included in the model. Assuming that structural breaks are known, he suggested various model specifications according to the structure of the break (Perron, 1989, p. 1364):

$$
\begin{aligned}
& \text { Model (A): } Y_{t}=\mu_{1}+\beta t+\left(\mu_{2}-\mu_{1}\right) D U_{t}+\alpha Y_{t-1}+\varepsilon_{t} \\
& \text { Model (B): } Y_{t}=\mu+\beta_{1} t+\left(\beta_{2}-\beta_{1}\right) D T_{t}+\alpha Y_{t-1}+\varepsilon_{t} \\
& \text { Model (C): } Y_{t}=\mu_{1}+\beta_{1} t+\left(\mu_{2}-\mu_{1}\right) D U_{t}+\left(\beta_{2}-\beta_{1}\right) D T_{t}+\alpha Y_{t-1}+\varepsilon_{t}(10)
\end{aligned}
$$

where $D U_{t}$ and $D T_{t}$ are dummy variables used to include breaks into the model, which may occur in constant and trend series respectively and are defined as follows: If $D U_{t}, t>T_{B}, 1$ takes the value of 0 in other cases. If $D T_{t}, t>T_{B}, t-T_{B}$ takes the value of 0 in other cases. Here, $T_{B}$ refers to break year and $t=1,2, \ldots, T$ refers to time. Model (A) is the equation that models the break in level and $\mu_{2}-\mu_{1}$ refers to the size of changes at $T_{B}$ time in a constant slope. Model (B) is the equation that models the break in trend and $\beta_{2}-\beta_{1}$ refers to the size of changes at $T_{B}$ time in a constant slope. It allows for changes in the trend without a sudden change in the level at the moment of the break. Finally, Model (C) is the equation that modes the break in level and in trend simultaneously. It allows for both effects to be accounted for at the same time?

Perron (1989) based the test procedure on the assumption that the break year is known in advance. However, this assumption has been criticized because the selection of the

\footnotetext{
${ }^{6}$ The test statistic calculated in the decision stage with the KPSS test is compared with the critical values provided by KPSS (1992).

7 The hypotheses for the Perron (1989) unit root test with one break and the formula used for the test statistic is the same as the ADF test. In the decision stage, the test statistic is compared with the critical values provided by Perron (1989).
} 
breakpoints based on the observation of data is not consistent with a test strategy based on a distribution that is thought to be independent of data (Libanio, 2005, p. 155). Zivot and Andrews (1992) developed this approach and suggested a new test for cases in which the break date is unknown in advance and is determined endogenously. The models for the ZA test are as shown in the equations below (Zivot \& Andrews 1992, p. 254):

$$
\begin{aligned}
& \text { Model A: } \Delta Y_{t}=\alpha Y_{t-1}+\mu_{o}+\beta_{o} t+\mu_{1} D U_{t}+\sum_{i=1}^{k} c_{i} \Delta Y_{t-i}+\varepsilon_{t} \\
& \text { Model B: } \Delta Y_{t}=\alpha Y_{t-1}+\mu_{o}+\beta_{o} t+\beta_{1} D T_{t}+\sum_{i=1}^{k} c_{i} \Delta Y_{t-i}+\varepsilon_{t} \\
& \text { Model C: } \Delta Y_{t}=\alpha Y_{t-1}+\mu_{o}+\beta_{o} t+\mu_{1} D U_{t}+\beta_{1} D T_{t}+\sum_{i=1}^{k} c_{i} \Delta Y_{t-i}+\varepsilon_{t}
\end{aligned}
$$

The $\Delta Y_{t-i}$ variable in the models is added to the right side of the equation to prevent the autocorrelation problem that may occur in the error term. According to the ZA test, $T_{B} / T$ gives the break year. To determine the break year for each break in the range of $j=2 / T$ and $j=(T-1) / T, t-2$, regressions are established by using the Least-Squares Method (LSM), and the break year for the model with the minimum $t$ statistics of $\alpha$ is determined as the appropriate break date (Zivot and Andrews 1992, p. 254-255). The test statistic obtained after determining the break year is compared with the critical values provided by Zivot and Andrews (1992) ${ }^{8}$.

In the studies of Perron (1989) and Zivot and Andrews (1992), preliminary information on the structural break is required. There is a need for information on whether the break has occurred endogenously or exogenously and suddenly or gradually. This is because these tests are based on certain assumptions regarding the number, type, and form of the break. Enders and Lee (2012) extended the classical DF equation with the Fourier approach and suggested a Fourier-ADF test that could capture all kinds of breaks when the structure, type, number, or form of the break is unknown. Thus, the basic DF model extended with the Fourier approach is as shown in Equation 14.

$$
\Delta Y_{t}=a(t)+\rho Y_{t-1}+b t+\varepsilon_{t}
$$

where $a(t)$ is the deterministic element that varies according to time and is calculated with the Fourier approach, as shown in Equation 14.1 (Enders \& Lee 2012, p. 575).

$$
a(t)=\theta_{o}+\sum_{k=1}^{n} \theta_{k} \sin (2 \pi k t / T)+\sum_{k=1}^{n} \delta_{k} \cos (2 \pi k t / T), \quad n \leq T / 2
$$

In Equation 14.1, $k$ represents a certain Fourier frequency number, $n$ represents the number of cumulative frequencies in the approach, and $T$ represents the number of

\footnotetext{
8 The hypotheses for the Zivot and Andrews (1992) unit root test with one break and the formula used for the test statistic is the same as the ADF test.
} 
observations. The method suggested by Davis (1987) is implemented in determining $k$. According to this model, the $k$ value that minimizes residual squares is selected. On that note, Enders and Lee (2012) suggest that $k$ be given values in the range of 1 and 5 (Enders \& Lee 2012, p. 581). After determining the $k$ value that minimizes residual squares, autocorrelations of residuals in the value determined should be checked ${ }^{9}$.

\section{Empirical Analysis}

In the empirical analysis section of the study, unit root tests were used to analyze whether the UIRP hypothesis for The Fragile Five countries is valid. In the analysis section, we used monthly data from Brazil, Indonesia, South Africa, and Turkey for the 2005M07-2019M12 period. As we could not access data for the same period for India, we conducted the analyses by considering the 2011M12-2017M07 period. We obtained data on the interest rates from the IMF database ${ }^{10}$ and data on the consumer price index (CPI) from the OECD database. ${ }^{11}$ For interest rates, we used monetary policy interest rates.

We calculated the UIRP series like the studies of Baharumshah et al. (2008) and Ferreira and León-Ledesma (2007). Moreover, we used the interest rates in the real form with the help of the consumer price index (CPI) variable to prevent deviations arising from price levels (Baharumshah et al., 2008; Ferreira and León-Ledesma 2007).

We benefited from unit root tests with different model structures to support the analysis results and observe possible differences that could occur in the results. Table 2 shows the results for linear unit root tests that do not consider breaks (DF (1979), ADF (1981), PP (1989), and KPSS (1992)). Table 3 shows the Perron (1989) test results that consider one break and detect the break exogenously. Table 4 shows the Zivot and Andrews (1992) test results that detect the break year endogenously. Finally, Table 5 shows the Enders and Lee (2012) Fourier-ADF test results that account for smooth breaks.

\footnotetext{
9 The hypotheses for Enders and Lee (2012) tests and the test statistic are the same as the ADF test. However, in the decision stage, the Fourier-ADF test statistic is compared with the critical values provided by Monte Carlo simulations.

${ }^{10}$ https://data.imf.org/regular.aspx?key=61545867, Accessed January 8, 2020.

${ }^{11} \mathrm{https}$ //data.oecd.org/price/inflation-cpi.htm, Accessed January 8, 2020.
} 
Table 2: Results from unit root tests without a break

\begin{tabular}{|c|c|c|c|c|c|c|c|c|}
\hline \multirow{3}{*}{ Countries } & \multicolumn{2}{|c|}{ DF } & \multicolumn{2}{|c|}{ ADF } & \multicolumn{2}{|c|}{ PP } & \multicolumn{2}{|c|}{ KPSS } \\
\hline & Statistic & $\operatorname{lag}$ & Statistic & lag & Statistic & Bandwidth & Statistic & Bandwidth \\
\hline & \multicolumn{8}{|c|}{ Constant Model } \\
\hline Brazil & $-2.966^{a}$ & 0 & $-3.364^{b}$ & 0 & $-3.326^{b}$ & 5 & $0.417^{\mathrm{c}}$ & 9 \\
\hline India & -1.191 & 0 & -0.014 & 2 & -1.019 & 11 & $0.826^{\mathrm{a}}$ & 6 \\
\hline Indonesia & $-2.140^{\mathrm{b}}$ & 0 & $-3.105^{b}$ & 1 & $-2.639^{c}$ & 6 & $0.512^{\mathrm{b}}$ & 10 \\
\hline South Africa & $-1.663^{c}$ & 0 & $-3.784^{a}$ & 0 & $-3.853^{\mathrm{a}}$ & 3 & 0.087 & 9 \\
\hline \multirow[t]{2}{*}{ Turkey } & $-3.506^{\mathrm{a}}$ & 0 & $-3.820^{\mathrm{a}}$ & 0 & $-3.803^{a}$ & 4 & 0.208 & 9 \\
\hline & \multicolumn{8}{|c|}{ Constant and Trend Model } \\
\hline Brazil & $-3.802^{\mathrm{a}}$ & 0 & $-3.777^{b}$ & 0 & $-3.952^{b}$ & 4 & 0.065 & 9 \\
\hline India & -2.387 & 0 & $-3.810^{\mathrm{b}}$ & 1 & -2.738 & 11 & $0.160^{\mathrm{b}}$ & 5 \\
\hline Indonesia & $-2.883^{c}$ & 0 & $-3.344^{c}$ & 1 & -2.870 & 5 & $0.259^{\mathrm{a}}$ & 10 \\
\hline South Africa & -2.629 & 0 & $-3.735^{b}$ & 0 & $-3.830^{\mathrm{b}}$ & 2 & 0.079 & 9 \\
\hline Turkey & $-3.859^{a}$ & 0 & $-3.861^{b}$ & 0 & $-3.855^{b}$ & 4 & $0.136^{\mathrm{c}}$ & 9 \\
\hline
\end{tabular}

Notes: The column "lag" values in the DF and ADF test results show the appropriate number of lags. The values in column "Bandwidth" in the PP and KPSS test results refer to the bandwidth. The maximum lag was determined as 12, and the appropriate number of lags was chosen according to the Schwarz information criterion. The Bartlett Kernel estimator was used in the PP and KPSS tests according to Newey West methods. a, $\mathbf{b}$ and $\mathbf{c}$ refer to the statistical significance level at $1 \%, 5 \%$, and $10 \%$, respectively.

Table 3: Results from unit root test with an exogenous sharp break (Perron, 1989)

\begin{tabular}{|c|c|c|c|c|c|c|c|c|c|c|c|c|c|}
\hline \multirow[b]{2}{*}{ Countries } & \multicolumn{3}{|c|}{ Brazil } & \multicolumn{3}{|c|}{ India } & \multicolumn{2}{|c|}{ Indonesia } & \multicolumn{2}{|c|}{ South Africa } & \multicolumn{3}{|c|}{ Turkey } \\
\hline & \multicolumn{3}{|c|}{$\begin{array}{c}\text { Statistic } \\
\left(T_{B}: 2017 \mathrm{M} 1\right)\end{array}$} & \multicolumn{3}{|c|}{$\begin{array}{c}\text { Statistic } \\
\left(T_{B}: 2013 M 2\right)\end{array}$} & \multicolumn{2}{|c|}{$\begin{array}{c}\text { Statistic } \\
\left(T_{B}: 2009 \mathrm{M3}\right)\end{array}$} & \multicolumn{2}{|c|}{$\begin{array}{c}\text { Statistic } \\
\left(T_{B}: 2009 \mathrm{M} 3\right)\end{array}$} & \multicolumn{3}{|c|}{$\begin{array}{c}\text { Statistic } \\
\left(T_{B}: 2007 \mathrm{M10}\right)\end{array}$} \\
\hline $\begin{array}{l}\text { Model } \\
\text { (A) }\end{array}$ & \multicolumn{3}{|c|}{$-3.719^{b}$} & \multicolumn{3}{|c|}{$-3.819^{b}$} & \multicolumn{2}{|c|}{$-4.565^{\mathrm{a}}$} & \multicolumn{2}{|c|}{$-4.026^{b}$} & \multicolumn{3}{|c|}{$-4.741^{a}$} \\
\hline $\begin{array}{l}\text { Model } \\
\text { (B) }\end{array}$ & \multicolumn{3}{|c|}{$-4.302^{b}$} & \multicolumn{3}{|c|}{$-3.974^{b}$} & \multicolumn{2}{|c|}{$-4.570^{a}$} & \multicolumn{2}{|c|}{$-3.756^{c}$} & \multicolumn{3}{|c|}{$-4.340^{b}$} \\
\hline $\begin{array}{l}\text { Model } \\
\text { (C) }\end{array}$ & \multicolumn{3}{|c|}{$-5.061^{a}$} & \multicolumn{3}{|c|}{$-4.186^{b}$} & & & \multicolumn{2}{|c|}{$-4.274^{b}$} & \multicolumn{3}{|c|}{$-4.441^{b}$} \\
\hline Critical & \multicolumn{3}{|c|}{$(\lambda=0.793)$} & \multicolumn{3}{|c|}{$(\lambda=0.205)$} & \multicolumn{4}{|c|}{$(\lambda=0.252)$} & \multicolumn{3}{|c|}{$(\lambda=0.155)$} \\
\hline Values & $1 \%$ & $5 \%$ & $10 \%$ & $1 \%$ & $5 \%$ & $10 \%$ & $1 \%$ & 5 & & $10 \%$ & $1 \%$ & $5 \%$ & $10 \%$ \\
\hline $\begin{array}{l}\text { Model } \\
\text { (A) }\end{array}$ & -4.33 & -3.75 & -3.46 & -4.39 & -3.77 & -3.47 & -4.39 & -3 & & -3.46 & -4.39 & -3.77 & -3.47 \\
\hline $\begin{array}{l}\text { Model } \\
\text { (B) }\end{array}$ & -4.38 & -3.82 & -3.50 & -4.41 & -3.80 & -3.49 & -4.51 & -3 & & -3.58 & -4.41 & -3.80 & -3.49 \\
\hline $\begin{array}{l}\text { Model } \\
\text { (C) }\end{array}$ & -4.70 & -4.04 & -3.69 & -4.65 & -3.99 & -3.66 & -4.78 & -4 & & -3.87 & -4.65 & -3.99 & -3.66 \\
\hline
\end{tabular}

Notes: The maximum lag was determined as 12., refers to break date. The break dates were determined by the Quandt-Andrews Breakpoint Tests. a, $\mathbf{b}$ and $\mathbf{c}$ refer to the statistical significance level at $1 \%, 5 \%$, and $10 \%$, respectively. 
Table 4: Results from unit root test with a sharp endogenous break (Zivot and Andrews, 1992)

\begin{tabular}{lccccccccc}
\hline \multirow{2}{*}{ Countries } & \multicolumn{4}{c}{ Model-A } & \multicolumn{3}{c}{ Model-B } & \multicolumn{2}{c}{ Model-C } \\
\cline { 2 - 10 } & Statistic & lag & $T_{B}$ & Statistic & lag & $T_{B}$ & Statistic & lag & $T_{B}$ \\
\cline { 2 - 9 } Brazil & $-5.503^{\mathrm{a}}$ & 1 & $2018 \mathrm{M} 05$ & $-5.171^{\mathrm{a}}$ & 1 & $2017 \mathrm{M} 09$ & $-5.899^{\mathrm{a}}$ & 1 & $2016 \mathrm{M} 12$ \\
India & $-4.772^{\mathrm{c}}$ & 1 & $2013 \mathrm{M} 02$ & $-5.168^{\mathrm{a}}$ & 1 & $2013 \mathrm{M} 04$ & $-5.225^{\mathrm{b}}$ & 1 & $2014 \mathrm{M} 01$ \\
Indonesia & $-5.779^{\mathrm{a}}$ & 1 & $2008 \mathrm{M} 12$ & $-5.590^{\mathrm{a}}$ & 1 & $2009 \mathrm{M} 09$ & $-6.313^{\mathrm{a}}$ & 1 & $2008 \mathrm{M} 12$ \\
South & -4.579 & 0 & $2006 \mathrm{M} 04$ & $-4.144^{\mathrm{c}}$ & 0 & $2006 \mathrm{M} 07$ & $-5.552^{\mathrm{b}}$ & 0 & $2007 \mathrm{M} 08$ \\
Africa & $-5.812^{\mathrm{a}}$ & 1 & $2007 \mathrm{M} 08$ & $-4.988^{\mathrm{a}}$ & 1 & $2009 \mathrm{M} 02$ & $-6.106^{\mathrm{a}}$ & 0 & $2006 \mathrm{M} 10$ \\
Turkey & & & & & & & & &
\end{tabular}

Notes: The values in column "lag" results show the appropriate number of lags. The maximum lag was determined as 12, and the appropriate number of lags was chosen according to the Schwarz information criterion $\boldsymbol{T}_{\boldsymbol{B}}$, refers to break date. a, $\mathbf{b}$ and $\mathbf{c}$ refer to the statistical significance level at $1 \%, 5 \%$, and $10 \%$, respectively.

Table 5: Results from unit root test with smooth breaks (Enders and Lee, 2012)

\begin{tabular}{lcccccc}
\hline & \multicolumn{2}{c}{ Constant Model } & \multicolumn{3}{c}{ Constant and Trend Model } \\
\cline { 2 - 6 } Countries & Statistic & $l a g$ & $k$ & Statistic & lag & $k$ \\
\hline Brazil & $-4.601^{\mathrm{a}}$ & 0 & 4 & $-4.950^{\mathrm{a}}$ & 0 & 4 \\
India & -0.326 & 2 & 2 & -3.083 & 2 & 2 \\
Indonesia & $-3.750^{\mathrm{c}}$ & 0 & 1 & $-4.793^{\mathrm{b}}$ & 0 & 1 \\
South Africa & $-3.978^{\mathrm{b}}$ & 0 & 1 & -3.956 & 0 & 2 \\
Turkey & $-4.242^{\mathrm{a}}$ & 0 & 2 & $-4.235^{\mathrm{b}}$ & 0 & 1 \\
\hline
\end{tabular}

Notes: The values in column "lag" results show the appropriate number of lags. The maximum lag was determined as 12, and the appropriate number of lags was chosen according to the Schwarz information criterion. $\mathrm{k}$ represents the frequency number, and the appropriate frequency number was determined with the value that minimizes residual squares. Test results were compared with the critical values provided by Enders and Lee (2012). a, b and $\mathbf{c}$ refer to the statistical significance level at $1 \%, 5 \%$, and $10 \%$, respectively.

For a more straightforward interpretation of the country-based results, Tables 2, 3, 4, and 5 are summarized in Table 6.

Table 6: The Interest Rate Parity for The Fragile Five Countries

\begin{tabular}{lccccc}
\hline & Brazil & India & Indonesia & South Africa & Turkey \\
\hline DF & $\sqrt{ }$ & X & $\sqrt{ }$ & X & $\sqrt{ }$ \\
ADF & $\sqrt{ }$ & $\sqrt{ }$ & $\sqrt{ }$ & $\sqrt{ }$ & $\sqrt{ }$ \\
PP & $\sqrt{ }$ & X & X & $\sqrt{ }$ & $\sqrt{ }$ \\
KPSS & X & X & X & $\sqrt{ }$ & $\sqrt{ }$ \\
Perron (One Break) & $\sqrt{ }$ & $\sqrt{ }$ & $\sqrt{ }$ & $\sqrt{ }$ & $\sqrt{ }$ \\
ZA & $\sqrt{ }$ & $\sqrt{ }$ & $\sqrt{ }$ & X & $\sqrt{ }$ \\
F-ADF & $\sqrt{ }$ & X & $\sqrt{ }$ & $\sqrt{ }$ & $\sqrt{ }$ \\
In General & $\sqrt{ }$ & X & $\sqrt{ }$ & & \\
\hline
\end{tabular}

Note: The table lists the results for the constant and trend models.

When we review the general results in Table 6, we see that the parity series for Brazil, Indonesia, and Turkey are generally stationary in the applied tests. At this point, we have strong evidence that the UIRP hypothesis is valid for Brazil, Indonesia, and Turkey. When we review the results for India, the results of unit root tests without breaks and the FourierADF test show that the parity series have unit roots (not stationary), while the results of the 
tests with one break show the series to be stationary. Thus, the UIRP hypothesis is valid according to the tests without breaks and the Fourier-ADF test, while the exact opposite holds according to the tests with one break. This shows that the parity series for India is sensitive to sharp structural breaks.

When the results for South Africa are examined, according to the tests without breaks and the tests with one break, it was concluded that the interest parity series for South Africa is stationary. However, the Fourier-ADF test results that account for smooth breaks show that the interest parity series has a unit root process. Therefore, the UIRP hypothesis is not valid for South Africa according to the results of the Fourier-ADF test, while it is valid according to the results of other applied tests. This difference in the results is probably because the Fourier-ADF test includes smooth breaks in the model. At this point, the importance of selecting the model that explains the data set in the best way in analyses on unit root tests becomes a subject of debate. Therefore, the period and the structure of the data set should be well known while selecting the model for the unit root test.

When the break dates obtained from the Perron (1989) and ZA (1992) tests are examined, it is seen that the break dates for Indonesia, South Africa, and Turkey are scattered around the period of the 2008 global financial crisis. This crisis, which affected the world, impacted many economic indicators and caused sudden breaks. When the breaking dates for Brazil are examined, it is seen that it coincided with the election period when there was political turmoil in the country. A comprehensive corruption investigation called "Lava Jato" was launched in 2014, with corruption in the country reaching its highest level. In this context, the president of the country was dismissed in 2016. In 2017, many politicians in the administration were arrested, and rumors of a political coup gained strength. Finally, Jair Bolsonaro won the 2018 elections when the country was in political turmoil. This period of political turmoil has shaken the country's economy significantly (Y1ldırım, 2020). For India, it is seen that the breaking period corresponds to the flood disaster period due to the monsoon rains, which the president of the country described as "the disaster of this millennium." The state has announced that it has allocated a fund of 170 million dollars to compensate for the material damage caused by this disaster ${ }^{12}$.

\section{Conclusion}

The convergence of interest rates provides information on which exchange rate the monetary authority targets (Lee \& Wu 2004, p. 1287). Empirically, the convergence of interest rates can be analyzed by testing the stationarity of nominal interest differences. This

\footnotetext{
${ }^{12}$ https://www.bbc.com/english/news/2013/06/130621_india_flood, Accessed January 8, 2020.
} 
study tests the validity of the uncovered interest parity hypothesis in The Fragile Five countries, grouped and named according to the fragilities in their economic structures. Knowing the exchange rate fluctuations in these countries, which are also developing markets, can help policymakers protect the national economy against possible risks in exchange rates and it can help them make plans for national and international economic indicators that depend on the exchange rate. Moreover, it is helpful for investors who plan to invest in these countries to foresee price movements and assess and direct their investments.

When we review the results in general, the IRP is valid for Brazil, Indonesia, and Turkey, meaning that the exchange rate tends to turn back to its average value. The stationary process of differences among interest rates increases the global capital integration among markets. This can limit national market preferences. In other words, changes in the US exchange rates, which were taken as the default foreign exchange rate in the study, can force policymakers into sudden and unfavorable policies at the national level and lead to a decrease in the extent of their authority on determining the exchange rate ((Baharumshah, Haw, \& Fountas,2005, p. 81). For Brazil, Sachsida et al. (2001) and Ferreira and LeónLedesma (2007), for Indonesia, Baharumshah et al. (2008) and Büberkök (2020), and for Turkey, Ferreira and León -Ledesma (2007) and Büberkökü (2020) supports our results.

A review of the results for India shows the IRP hypothesis to be valid according to the results of ZA and Perron (1989) tests. However, the IRP hypothesis was not valid according to the results of other tests that did not include breaks and smooth breaks. These results are supported by Francis et al. (2002) and Bhatt and Virmani (2005). The sensitivity of India's parity series against sharp breaks stands out in the results. This is because these tests assume that sharp breaks have occurred.

The results for South Africa also reveal the effect of selecting the appropriate test on the results. This is because differences in the applied test method have led to different results. Other tests that were applied provided results that proved the validity of the IRP hypothesis. These results are supported by Büberkök (2020). Meanwhile, the Fourier-ADF test results that include smooth breaks showed the IRP hypothesis to be invalid in relevant countries. Keeping this in mind, we suggest researchers apply specification tests correctly and be well aware of the structural features of the analysis period for the selection of the test and to model accordingly. Moreover, the results of the validity of the parity hypothesis change when we take smooth breaks for South Africa into consideration. So, we suggest policymakers in South Africa take any smooth breaks that may occur within economic circumstances into consideration.

In conclusion, empirical findings show that the degree of financial market integration has increased with the financial liberalization process in Brazil, Indonesia, South Africa, and 
Turkey, which we can classify as emerging markets. In these countries, financial markets are not able to offer unbounded gains from arbitrage opportunities. Moreover, in these countries, monetary policy does not affect real interest rates in the long run. The fact that interest rate parity is not valid in India shows that financial integration has not been fully realized. Government interventions are not effective in returning the interest rate to equilibrium in the long run. In addition, the invalidity of the interest rate parity indicates the existence of high arbitrage opportunities for investors. However, considering that the trust environment is not at a reasonable level in India, the risk premium should be considered when making financial investments.

Peer-review: Externally peer-reviewed.

Conflict of Interest: The author has no conflict of interest to declare.

Grant Support: The author declared that this study has received no financial support.

\section{References}

Adrangi, B., Raffiee, K., \& Shank, T. M. (2007). An ex-post investigation of interest rate parity in Asian emerging markets. International Business \& Economics Research Journal (IBER), 6(2), 29-48. https://doi.org/10.19030/ iber.v6i2.3342.

Aslan, Ö., \& Korap, H. L. (2010). Does the uncovered interest parity hold in short horizons?. Applied Economics Letters, 17(4), 361-365. 10.1080/13504850701735781.

Baharumshah, A. Z., Haw, C. T., \& Fountas, S. (2005). A panel study on real interest rate parity in East Asian countries: Pre-and post-liberalization era. Global Finance Journal, 16(1), 69-85. https://doi.org/10.1016/j. gfj.2005.05.005.

Baharumshah, A. Z., Haw, C. T., Masih, A. M. M., \& Lau, E. (2011). Financial integration of East Asian economies: evidence from real interest parity. Applied Economics, 43(16), 1979-1990. https://doi. org/10.1080/00036840902902243.

Baharumshah, A. Z., Liew, V. K. S., \& Hamzah, N. A. (2008). Real interest rate parity in the ASEAN-5 countries: A nonlinear perspective. Applied Economics Letters, 15(12), 955-958. https://doi. org/10.1080/13504850600949152.

Baharumshah, A. Z., Liew, V. K. S., \& Haw, C. T. (2009). The real interest rate differential: international evidence based on non-linear unit root tests. Bulletin of Economic Research, 61(1), 83-94. https://doi. org/10.1111/j.1467-8586.2008.00288.x.

Balke, N. S., \& Wohar, M. E. (1998). Nonlinear dynamics and covered interest rate parity. Empirical Economics, 23(4), 535-559. 10.1007/BF01205993

Batten, J. A., \& Szilagyi, P. G. (2010). Is covered interest parity arbitrage extinct? Evidence from the spot USD/ Yen. Applied Economics Letters, 17(3), 283-287. https://doi.org/10.1080/13504850701720189.

BBC, https://www.bbc.com/english/news/2013/06/130621_india_flood, Access Date: January 8, 2020.

Bekaert, G., Wei, M., \& Xing, Y. (2007). Uncovered interest rate parity and the term structure. Journal of International Money and Finance, 26(6), 1038-1069. https://doi.org/10.1016/j.jimonfin.2007.05.004.

Berument, H., \& Günay, A. (2003). Exchange rate risk and interest rate: a case study for Turkey. Open economies review, 14(1), 19-27. doi:10.1023/A:1021243101272 
Bhatt, V., \& Virmani, A. (2005). Global integration of India's Money Market: Interest rate parity in India (No. 164). Working Paper.

Bhatti, R. H. (2014). The existence of uncovered interest parity in the CIS countries. Economic Modelling, 40, 227241.https://doi.org/10.1016/j.econmod.2014.04.002.

Büberkökü, Ö. (2020). Bazı Gelişen Piyasa Ekonomilerinde Garantisiz (Uncovered) Faiz Oranı Paritesinin Geçerliliğinin İncelenmesi. Maliye Dergisi 177, 160-176.

Chang, H. L., \& Su, C. W. (2015). Uncovered interest parity and monetary integration in East Asian countries based on China. The Journal of International Trade \& Economic Development, 24(4), 451-464. https://doi.org/10.10 80/09638199.2014.920402.

Chin, C. C., \& Liang, H. M. (2009). The long-run uncovered interest rate parity in view of a trading strategy. Applied Economics, 41(21), 2727-2739. https://doi.org/10.1080/00036840701320225.

Claassen, E-M. (1996). Global Monetary Economics. Oxford University Press: New York.

Coleman, A. (2012). Uncovering uncovered interest parity during the classical gold standard era, 1888-1905. The North American Journal of Economics and Finance, 23(1), 20-37. https://doi.org/10.1016/j.najef.2011.10.001.

Committeri, M., Rossi, S., \& Santorelli, A. (1993). Tests of covered interest parity on the Euromarket with highquality data. Applied Financial Economics, 3(1), 89-93. https://doi.org/10.1080/758527822.

Davis, E. P. (1987). A stock-flow consistent macro-econometric model of the UK economy-part I. Journal of Applied Econometrics, 2(2), 111-132. https://doi.org/10.1002/jae.3950020204

Dickey, D. A., \& Fuller, W. A. (1979). Distribution of the estimators for autoregressive time series with a unit root. Journal of the American statistical association 74 (366a), 427-431. https://doi.org/10.1080/01621459.1979.10 482531.

Dickey, D. A., \& Fuller, W. A. (1981). Likelihood ratio statistics for autoregressive time series with a unit root. Econometrica: journal of the Econometric Society, 1057-1072. 10.2307/1912517.

Einzig, P. 1937. The Theory of Forward Exchange. Macmillan, London.

Enders, W., \& Lee, J. (2012). A unit root test using a Fourier series to approximate smooth breaks. Oxford bulletin of Economics and Statistics, 74(4), 574-599. https://doi.org/10.1111/j.1468-0084.2011.00662.x.

Erdemlioğlu, D. M. (2007). A new test of uncovered interest rate parity: evidence from Turkey. MPRA, Paper No: 10787: 1-20.

Feenstra, R. C., \& Taylor, A. M. (2012). International Macroeconomics, 2nd edition, Worth Publishers.

Ferreira, A. L., \& León-Ledesma, M. A. (2007). Does the real interest parity hypothesis hold? Evidence for developed and emerging markets. Journal of International Money and Finance, 26(3), 364-382. https://doi. org/10.1016/j.jimonfin.2006.11.003.

Fong, W. M., Valente, G., \& Fung, J. K. (2010). Covered interest arbitrage profits: The role of liquidity and credit risk. Journal of banking \& finance, 34(5), 1098-1107. https://doi.org/10.1016/j.jbankfin.2009.11.008.

Francis, B. B., Hasan, I., \& Hunter, D. M. (2002). Emerging market liberalization and the impact on uncovered interest rate parity. Journal of International Money and Finance, 21(6), 931-956. https://doi.org/10.1016/ S0261-5606(02)00029-3.

Fukuda, S. I. (2016). Regional liquidity risk and covered interest parity during the global financial crisis: evidence from Tokyo, London, and New York. International Economic Journal, 30(3), 339-359. https://doi.org/10.1080/ 10168737.2016.1211842.

Glahe, F. R. (1967). An empirical study of the foreign-exchange market: test of a theory (No. 20). International Finance Section, Department of Economics, Princeton University.

Goh, S. K., Lim, G. C., \& Olekalns, N. (2006). Deviations from uncovered interest parity in Malaysia. Applied Financial Economics, 16(10), 745-759. https://doi.org/10.1080/09603100500404231. 
Goodwin, B. K., \& Grennes, T. J. (1994). Real interest rate equalization and the integration of international financial markets. Journal of International Money and Finance, 13(1), 107-124. https://doi.org/10.1016/02615606(94)90027-2.

Guender, A., \& Cook, B. (2011). Monetary policy implementation and uncovered interest parity: empirical evidence from Oceania. New Zealand Economic Papers, 45(3), 209-229. https://doi.org/10.1080/00779954.2011.57164 3.

Hayaloğlu, P. (2015). Kırılgan beşli ülkelerinde finansal gelişme ve ekonomik büyüme ilişkisi: Dinamik panel veri analizi. Ekonomik ve Sosyal Araştırmalar Dergisi, 11(1), 131-144.

Holmes, M. J., \& Maghrebi, N. (2004). Asian real interest rates, nonlinear dynamics, and international parity. International Review of Economics \& Finance, 13(4), 387-405. https://doi.org/10.1016/j. iref.2003.06.001.

Husted, S., \& M. Melvin. (2013). International Econometrics. 9th Ed., New Jersey: Pearson Education.

IMF, https://data.imf.org/regular.aspx?key=61545867, Access Date: January 8, 2020.

IMF, https://data.oecd.org/price/inflation-cpi.htm, Access Date: January 8, 2020.

Ito, T. (1988). Use of (time-domain) vector autoregressions to test uncovered interest parity. The review of Economics and Statistics, 296-305. 10.2307/1928314.

Jiang, C., Li, X. L., Chang, H. L., \& Su, C. W. (2013). Uncovered interest parity and risk premium convergence in Central and Eastern European countries. Economic Modelling, 33, 204-208. https://doi.org/10.1016/j. econmod.2013.04.025.

Jorion, P. (1996). Does real interest parity hold at longer maturities?. Journal of International Economics, 40(1-2), 105-126. https://doi.org/10.1016/0022-1996(95)01384-9.

Kapetanios, G., Shin, Y., \& Snell, A. (2003). Testing for a unit root in the nonlinear STAR framework. Journal of econometrics, 112(2), 359-379. https://doi.org/10.1016/S0304-4076(02)00202-6.

Karahan, Ö., \& Çolak, O. (2012). Does uncovered interest rate parity hold in Turkey?. International Journal of Economics and Financial Issues 2(4):386-394.

Keynes, J. M. (1923). A Tract on Monetary Reform. MacMillan and St. Martin's Press for The Royal Economic Society, London.

Kim, H., \& Cho, J. (2011). A test of the revised interest parity in China and Asian emerging markets. Emerging markets finance and trade, 47(sup4), 23-41. https://doi.org/10.2753/REE1540-496X4705S402.

Krugman, P. R., \& Obstfeld, M. (2003). International economics: theory and policy. US: Pearson Education.

Krugman, P. R., and Obstfeld, M. (2009). International Economics: Theory and Policy. 8th Ed., Boston: Pearson Education.

Kugler, P., \& Neusser, K. (1993). International real interest rate equalization. A multivariate time-series approach. Journal of Applied Econometrics, 8(2), 163-174. https://doi.org/10.1002/jae.3950080205.

Kwiatkowski, D., Phillips, P. C., Schmidt, P., \& Shin, Y. (1992). Testing the null hypothesis of stationarity against the alternative of a unit root: How sure are we that economic time series have a unit root?. Journal of econometrics, 54(1-3), 159-178.

Lee, H. Y., \& Wu, J. L. (2004). Convergence of interest rates around the Pacific Rim. Applied Economics, 36(12), 1281-1288. https://doi.org/10.1080/0003684042000238929.

Libanio, G. A. (2005). Unit roots in macroeconomic time series: theory, implications, and evidence. Nova Economia, 15(3), 145-176. https://doi.org/10.1590/S0103-63512005000300006.

Lily, J., Kogid, M., Abd Karim, M. R., Asid, R., \& Mulok, D. (2011). Empirical testing on uncovered interest rate parity in Malaysia. Journal of Applied Finance and Banking, 1(2), 95. 
Lily, J., Kogid, M., Mulok, D., \& Asid, R. (2012). Revisiting Uncovered Interest Rate Parity: An Empirical Testing Using Bounds Test Approach. Procedia Economics and Finance, 2, 45-52. https://doi.org/10.1016/S22125671(12)00063-9.

Lothian, J. R. (2016). Uncovered interest parity: The long and the short of it. Journal of Empirical Finance, 36, 1-7. https://doi.org/10.1016/j.jempfin.2015.12.001.

Lothian, J. R., \& Wu, L. (2011). Uncovered interest-rate parity over the past two centuries. Journal of International Money and Finance, 30(3), 448-473. https://doi.org/10.1016/j.jimonfin.2011.01.005.

McAVINCHEY, I. D., \& MacDONALD, R. (1990). Some specification tests of uncovered interest parity. Recherches Économiques de Louvain/Louvain Economic Review, 61-78.

Melvin, M., \& Norrbin, S. C. (2013). International Money and Finance. 8th Ed., Oxford: Elsevier.

Mishkin, F. S. (1984). Are real interest rates equal across countries? An empirical investigation of international parity conditions. The Journal of Finance, 39(5), 1345-1357. https://doi.org/10.1111/j.1540-6261.1984. tb04911.x.

Moosa, I. A. (1996). An empirical investigation into the causes of deviations from covered interest parity across the Tasman. New Zealand Economic Papers, 30(1), 39-54. https://doi.org/10.1080/00779959609544248.

MSCI, https://www.msci.com/market-classification, Access Date: January 8, 2020.

Mylonidis, N., \& Semertzidou, M. (2010). Uncovered interest parity puzzle: does it really exist?. Applied Economics Letters, 17(10), 1023-1026. https://doi.org/10.1080/00036840902762696.

Pasricha, G. K. (2006). Survey of literature on covered and uncovered interest parities. MPRA Paper No. 22737. https://mpra.ub.uni-muenchen.de/22737/.

Perron, P. (1989). The great crash, the oil price shock, and the unit root hypothesis. Econometrica: journal of the Econometric Society, 1361-1401. 10.2307/1913712.

Phillips, P. C. B., \& P. Perron (1988). Testing for a Unit Root in Time Series Regression. Biometrika 75(2), 335346. https://doi.org/10.1093/biomet/75.2.335

Pipatchaipoom, O., \& Norrbin, S. C. (2010). Is the real interest rate parity condition affected by the method of calculating real interest rates?. Applied Economics, 42(14), 1771-1782. https://doi. org/10.1080/00036840701736073.

Rowland, P. (2003). Uncovered interest parity and the USD/COP exchange rate. Borradores de Economía; No. 227. https://doi.org/10.32468/be.227.

Sachsida, A., Ellery Jr, R., \& Teixeira, J. R. (2001). Uncovered interest parity and the peso problem: the Brazilian case. Applied Economics Letters, 8(3), 179-181. https://doi.org/10.1080/13504850150504559.

Sharpe, I.G. (1984). Covered Interest Rate Parity: The Australian Case. Applied Economics 16 (5), 655-665. https:// doi.org/10.1080/00036848400000016.

Skinner, F. S., \& Mason, A. (2011). Covered interest rate parity in emerging markets. International Review of Financial Analysis, 20(5), 355-363. https://doi.org/10.1016/j.irfa.2011.06.008.

Stanley, M. (2013). FX Pulse. New York: Morgan Stanley.

Stein, J. L. (1962). The nature and efficiency of the foreign exchange market (No. 40-45). International Finance Section, Dept. of Economics, Princeton University.

Suh, S., \& Kim, Y. J. (2016). Covered interest parity and arbitrage paradox in emerging markets: Evidence from the Korean market. Pacific-Basin Finance Journal, 38, 161-176. https://doi.org/10.1016/j.pacfin.2016.04.003.

Taylor, M. P. (1987a). Covered interest parity: a high-frequency, high-quality data study. Economica, 429-438. $10.2307 / 2554178$.

Taylor, M. P. (1987b). Risk premia and foreign exchange: a multiple time series approach to testing uncovered interest-rate parity. Weltwirtschaftliches archiv, 123(4), 579-591. 10.1007/BF02708567. 
Taylor, M. P. (1989). Vector autogressive tests of uncovered interest rate parity with allowance for conditional heteroscedasticity. Scottish Journal of Political Economy, 36(3), 238-252. https://doi. org/10.1111/j.1467-9485.1989.tb01090.x.

Tse, Y., \& Wald, J. K. (2013). Insured uncovered interest parity. Finance Research Letters, 10(4), 175-183. https:// doi.org/10.1016/j.frl.2013.06.004.

Yıldırım, Y. (2020). Lula da Silva'dan Bolsonaro’ya Brezilya’da Siyasal Dönüşüm. Mülkiye Dergisi, 44(3), 515542.

Zivot, E., \& Andrews, D. W. K. (1992). Further evidence on the great crash, the oil-price shock, and the unit-root hypothesis. Journal of business \& economic statistics, 20(1), 25-44. https://doi. org/10.1198/073500102753410372. 
